\title{
The Role of Service Quality in Enhancing Customer Satisfaction in Jordanian Public Universities
}

\author{
Sattam allahawiah ${ }^{*}$ Sultan altarawneh Suleiman alqudah \\ 1. Albalqa Applied University \\ 2. mutah university \\ 3. mutah university
}

\begin{abstract}
The relationship between university student orientation, perceived education service quality (education quality, supervision quality), and student satisfaction of engineering student in public universities in the south of Jordan is the main purpose of this study. The three main public universities (Mutah, Al-Tafila and Al-Hussein) were included in this research represented by their faculties of engineering.

Statistical techniques were used in analyzing all data by using statistical program (spss v.23) as well as the tools and methods of statistics such as simple and multi regression analysis, and path analysis using OMOS7 program. Verification of validity of the survey as well as the relatability and the internal consistency has been assured with respect to all standards.

The statistical analysis indicates a medium level of student orientation and a slightly high level of perceived education service level which made students less satisfied. Student orientation affects positively perceived education quality as well as student satisfaction, in addition the two components of education service quality have a considerable influence on student satisfaction. As shown from statistical analysis, influence of student orientation on education quality and student satisfaction is clear, paying more attention to quality dimensions by universities, and improving supervision quality in addition to the importance of the positive influence of service quality education on student satisfaction are some of the most important recommendations of the study for both public universities in Jordan and researchers who are interested in this type of studies.
\end{abstract}

Keywords: education quality, service quality, satisfaction student orientation, Assurance.

DOI: $10.7176 / \mathrm{EJBM} / 11-1-13$

\section{Introduction}

For the last few decades there have been considerable revolutionary developments in the service sector which resulted in more awareness of the importance of this sector in promoting the economy of countries. It has become one of the most sought-after subjects for scholars and planners.

It is well known that educational institutions and most importantly universities play the most important role in sustaining development in all countries. Since development essentially depends on human resources, universities are considered the fundamental institutions responsible for providing countries with highly qualified graduates out of whom there will emerge leaders, planners, developers and workers in social, economic, scientific and political areas.

There has recently been a tremendous increase in the number of universities in Jordan and this eventually lead to a comparative increase in the number of university students as well.

The total number of universities in Jordan is thirty universities, eleven of them provide high education programs. All of them have engineering faculties (www.mohe.gov.jo,2018).

Universities pay more attention to their students through special programs to qualify and prepare them to be the future development leaders. As the number of students increase, universities become more interested in students' ideas and opinion and offer them better services because students are their principal customers. Students have many alternatives to choose from. Thus, they will choose the university that meets their needs better.

In order to evaluate the perceived educational services presented to students and determine strong and weak points in the programs offered by universities, keeping up with developments and changes in the nature and standard of better service quality offered is essential.

Service institutions, including educational institutions have become obsessed with quality management and customer satisfaction to develop and improve their services. Thus, customer satisfaction has assumed a central position of their interest, and they are constantly trying to recognize the needs and expectations of their customers and provide services that guarantee their satisfaction which has recently become even more challenging because of the accelerating developments in communication methods and information technology. The customer can compare and choose the service he/she requires. As a result, many institutions have adopted 
customer orientation as an entry to achieve their long-term satisfaction. To evaluate and understand the present and future needs and wishes of the customer, positive factors affecting customer satisfaction and finding the values that customers considers valuable is needed to evaluate the customer orientation. The most successful organization concentrates its efforts on evaluating its customer's needs and wishes irrespective of product. The product can be services or goods. In addition, it concentrates on the implemented procedures in all service departments and sections (Zeineddin, 1996).

Based on the above-mentioned argument; this research seeks a method to evaluate the expected effects of student satisfaction measures and service quality methods provided by the university on the extent of student satisfaction.

\section{Statement of problem}

Over the last few decades a growing interest was allocated towards the quality of teaching services offered by various institutions; governmental and otherwise. the extent of customer satisfaction has also been recognized as a leading factor in the assessment of the quality of services offered by these institutions. The advent of technology in communication and interactive media has made it possible for those involved in teaching and learning to utilize them in their services. Along with the growing awareness of the concept of quality by both ends of the equation: the service providers and the recipients; attention has been further renewed towards this process. To ensure best teaching and learning results; the assessment of quality acquired utmost importance.

This assessment must be viewed in a precise and systematic method that guarantees accuracy and fairness about both terminals of the service. The inclusion of new methods in the teaching process made available by advancing technology made it necessary for the investigator of this phenomenon to include new parameters that needed to be studied. It is the intention of this work to illustrate and quantify those factors related to customer satisfaction as pertaining to the quality of services provided by the governmental academic institutions in the south of Jordan.

Total quality management is considered as a main challenge facing most of the organizations in the Hashemite kingdom of Jordan. This challenge is a result of administrational and technological deterrents.

One of the most important aspects in this field is deficiency in achieving the satisfaction of customers by these organizations. Customer satisfaction will be more critical in the future than it is now. With no proper guidance and directions, the effort exerted by universities to improve and compete will be in vain. Achieving customer satisfaction in educational organization is very important and it is an essential element for persistence and durability of educational organization. Few researches have been done in Jordan that focused on customer satisfaction in public universities. This study is concerned with the illustration of the nature of educational service quality in public universities in the south of Jordan and its dependence on customer satisfaction (student) to increase the presented service quality in order to achieve the direct influence on customer satisfaction.

\section{Questions of the study}

This study comes to answer the following questions

1. To what extent will the student orientation performed by the university participate in the customer satisfaction (student) in Jordanian public universities?

2. To what extent will the student orientation performed by universities affect the educational quality service (educational quality, supervising quality) in Jordanian public universities?

3. To what extent will the educational service quality (educational quality, supervising quality) affect the customer satisfaction (student) in Jordanian public universities?

4. To what extent does service quality offered in both educational and supervision affect enhancing the customer orientation in Jordanian public universities?

5. Are public universities able to implement total quality management to improve their services in their attempt to meet the students' needs and expectations?

\section{Research Objectives}

The main purpose of this study concentrates on the possible effects of student's orientation measures performed by the universities involved in this study on the extent of student satisfaction which can be achieved. This is done by studying the influence of student orientation on satisfaction, so the objectives of the study are set as follow:

1. Studying the influence of student orientation measures performed by the universities on the customer satisfaction (student) in public universities. 
2. Identifying the influence of student orientation measures performed by the universities on the achieved educational quality service (educational quality, supervising quality) in public universities.

3. Testing the influence of achieved educational service quality (educational quality, supervising quality) on the extent of customer satisfaction (student) in public universities.

4. Studying the role of achieved educational service quality (educational quality, supervising quality) as a variable of reinforcement of students' orientation. And exploring the effects of the achieved educational service quality on customer satisfaction (student) in Jordanian public universities.

5. Identifying the influence of the student orientation performed by the university on the quality of educational service (educational quality, supervising quality).

6. Testing the quality of educational service measures offered by the universities involved in the study.

7. Studying the role of educational quality service offered in enhancing the student's orientation to achieve the best levels of students' satisfaction.

\section{5 .study hypotheses}

According to the statement of the study, the following proposed hypotheses are to be tested:

Hypothesis O 1: There is no influence of statistical significance of student orientation on their satisfaction at significant level 0.05 .

Hypothesis $\mathrm{O} 2$ : There is no influence of statistical significance of student orientation on quality of educational service in the universities involved in this study at significance level 0.05 .

Hypothesis O 3: There is no influence of statistical significance of quality of educational service on student's satisfaction at significant level 0.05 .

Hypothesis O 4: There is no indirect statistical significance influence of student's orientation on their satisfaction with the presence of quality of educational service at significance level 0.05 .

\section{6. importance of the study}

This study derives its importance from the importance of student orientation. That orientation scheme in the university will eventually lead to achieving high levels of customer satisfaction. This study also investigates the extent of educational service quality offered by universities. The role of achieved educational service quality (educational quality, supervising quality) in enhancing student orientation and customer satisfaction is undeniable. This necessitates that more efforts be exerted by the educational organizations. This study is best considered as an initial and preliminary step which may enhance other researchers to embark on further studies that concentrate on the importance of student orientation schemes and the achieved educational service quality in the path of attaining customer (student) satisfaction.

This study can also be used practically as a reference to estimate the factors of long term performance of developing universities; through identifying the needs and desires of their students.

\section{Previous studies}

In this part of the discussion a few related studies will be quickly reviewed.

Research has ascertained that an abundance of higher educational institutions follows traditional styles of evaluation of teaching methods following the belief that these methods will be able to produce the desired goals of the teaching process in a review by Ibrahim (2007) entitled "personal aspects and their relation to quality and the level of teaching" on students of marine transport college students. The researcher also ascertained that at the same time and for contrast; successful experiments of leading higher educational institutions of the world confirmed the necessity of abiding by the methods of quality assessment of services offered to students. He stated that this is due to the fact that these methods provide better assessment of the dimensions of quality in educational services from the standpoint of students. And he finally concluded that these modern methods will eventually lead to better introduction of improvements to the educational systems and consequently leading to a higher profile and a more competitive status of these educational institutions. Profit making, and expansion are two added benefits too.

An attempt was made to understand the effects of concepts of services offered by universities and the recognition of the attractive elements of these services on the decision of students to enrol in that university. This was explored by Alruba'ee and Laitth, 2008 in a published study entitled "factors that attract foreign students in Petra University targeting international students". They stated that this effort will eventually aid the university in placing a suitable strategy that can attract foreign students to that university. Petra University was chosen for the research and the domain covered all foreign students enrolled to that university in all disciplines and all academic levels. The number of students investigated totalled 995 according to the records of that university around 10-4-2005 and the percentage was $25.5 \%$ of total number of students. An attempt was made to list the obstacles that face students and supervisors and other parties related to postgraduate research. 
The literature also revealed an investigational effort aimed at determining the effect of positive interaction between students and supervisors. And the effect this interaction has on the receivers of the educational services. The study tried to evaluate supervisors from the viewpoint of students in a study by Wright entitled "student evaluations and customer orientation of universities" Researchers also explored the effects of implementing and improving the collegiate student orientation scale in a work published by Bristow \& Schneider in 2002 entitled "The collegiate student orientation scale (ASOS): application of the marketing concept to higher education" The sample chosen was students of "Large Mid-Western State University" and concluded that the scale tested was highly credible. Measuring the three-main dimension of quality: quality design, quality applicability, and quality performance in a study by Widrich entitled "measuring the dimensions of quality in higher education"The sample chosen was administrative and educational staff members of "Rochester Institute of Technology". Many issues were tackled in that study among which was: evaluation of the quality of research, mechanism of improving curricula and the necessary instruments to achieve that goal.Many results were extracted. The most important result was that abiding to the three dimensions of quality leads to proper and contemporary standards of schemes.

Designing and application of a satisfaction model was attempted in a study by Douglas entitled "measuring student satisfaction at a UK university". The study was applied on the student of the colleges of law and business administration in the University of Liverpool. The sample chosen was all the enrolled students and the result deduced was that there are so many aspects pertaining to the educational process that the least important aspect was the financial aspect. Investigating the effect of applying the theories of market orientation on the public university in Spain was attempted. The relationship between four factors on one side with quality assurance on the other hand was also investigated. The four factors were: trust, control, professional autonomy and accountability in a study by Hoecht in 2006 entitled "quality assurance in UK higher education"

The result concluded was that there is a positive relationship between the four factors and the quality of service in education.

Testing the concept of students as customers from the viewpoint of the academic staff members was attempted in a study by Lomas in 2007 entitled "are students customers? Perceptions of academic staff"The sample was the academic staff members of a group of American universities specialized in humanitarian sciences. The result deducted from that study was that students are the founding stone of educational institutions and they are the most important and essential customers of these institutions.

Investigating the application of the "collegiate student orientation scale" on students of the college of business in "Large Mid-Western State University" was investigated in study by Pesch in 2008 entitled "the student orientation of a college of business: an empirical look from the student's perspective" and concluded that scale is credible, but some psychological issues exist that hinder its accuracy.

Testing the level of market orientation of students and staff members in AACSB schools was explored in a work published by Hammond in 2009 entitled "the impact of market orientation towards students and student/faculty ratios on performance " Many results were deduced. The most important result was that there were variations between the opinions of the sample members on the level of market orientation of students and the limits of future research of market orientation of educational institutions.

\section{Population of the study}

The population of the study consists of all engineering students in three public universities in the south of Jordan (Mutah, Altafila and Al-Hussein) universities. The total number of the population was 5023as it is reported in the websites of the university of Mutah and the university of Altafila while the number of engineering students in Al-Hussein university has been collected by personal contact with the university.

\section{Sample of the study}

The sample of the study will be chosen randomly from engineering students of the society of the study. The minimum number of the sample size is calculated according to a specific equation that will be mentioned below. That equation revealed that 188 students is the minimum sample size with a marginal error of 0.05 and a confidence level of $95 \%$. A total of 300 students were participating in the survey. The questionnaire forms were distributed to the sample members and (273) of forms have been collected back. Of these recollected forms (18) were excluded for disqualification and un-validity for statistical analysis. Therefore, (255) forms with $85 \%$ are going to be statistically analysed.

\section{Demographic distribution of the sample members}

The demographic distribution of the elements of the sample is illustrated in table 3.1 
Table 3-1 showing demographic distribution of sample members

\begin{tabular}{|c|c|c|c|c|}
\hline NO & \multicolumn{2}{|l|}{ Variable } & NO. of sample & Percentage \\
\hline \multirow[t]{3}{*}{1} & University & Mutah & 101 & $40 \%$ \\
\hline & & Al-Tafila & 78 & $31 \%$ \\
\hline & & Al-Hussein & 76 & $29 \%$ \\
\hline \multicolumn{4}{|l|}{ Total } & 100.0 \\
\hline \multirow[t]{2}{*}{2} & Sex & Male & 170 & $67 \%$ \\
\hline & & Female & 85 & $33 \%$ \\
\hline \multicolumn{4}{|l|}{ Total } & 100 \\
\hline \multirow[t]{6}{*}{3} & Experience & $1^{\text {st }}$ year & 68 & $27 \%$ \\
\hline & & $2^{\text {nd }}$ year & 86 & $34 \%$ \\
\hline & & $3^{\text {rd }}$ year & 43 & $17 \%$ \\
\hline & & $4^{\text {th }}$ year & 33 & $13 \%$ \\
\hline & & $5^{\text {th }}$ year & 11 & $4 \%$ \\
\hline & & More than 5 & 14 & $5 \%$ \\
\hline \multicolumn{4}{|l|}{ Total } & 100 \\
\hline
\end{tabular}

As shown in table (3-1) most of the sample members are Mutah university students. Their portion of the whole sample was $40 \%$. There were 85 female students with a percentage of $33 \%$ of the sample. Male students occupied $67 \%$ of the sample size with 170 students. The 5th year students portion was the smallest with a $4 \%$ share. the 2nd year students were the largest portion with $34 \%$. The students of more than 5 years' experience were represented with $5 \%$. 4th year students were represented with $13 \%$. 3rd year students participated with $17 \%$. And 1 st year students participated with $27 \%$ of the sample size. To achieve the target of the study, the following tools will be used to obtain and collect the needed data and information. This data will be then analyzed and investigated:

In spite of the variety of measuring methods, this study has the 7th measuring method, so the answer of questions will be choosing one of seven answers as shown below

Question

\section{Answer}

\section{Agree Moderately Agree}

\section{Neutral Slightly \\ Disagree}

\section{Disagree Strongly Disagree}

\section{1. statistical methods used in the study}

In order to evaluate and measure the hypothesis of the study the following statistical methods were used:

1- "Cronbach alpha" was used to evaluate the reliability of the study.

2- Frequency distribution and percentage.

3- Measure of central tendency.

4- Variance measurements.

5- Regression tests.

6- Goodness of fit (GOF).

7- The Bentler-Bonnet normed fit index (NFI).

8- Comparative fit index (CFI).

9- Chi-Square.

10-Analysis of moment structures. 
11- Relative importance.

Relative importance is defined as:

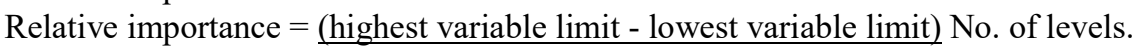

$$
\text { So, } \quad(7-1) / 3 \quad=2
$$

- $\quad$ Low

- Medium

- High

low levels: when mean value lies between $1-<3$

Medium levels: when mean value lies between $3-<5$

High levels: when mean value lies between $5-7$

\section{Analysis of Results and Testing of Hypothesis}

In this section, statistical analysis of the answers of the sample members will be discussed. The mean and standard deviation for each variable will be calculated. testing of hypothesis will be performed. in addition to the direct and indirect effect of the variables of the questionnaire. So, the results will be discussed as follows:

\subsection{Descriptive statistical indicators of study variables}

Statistical indicators which can be gained from the analysis of the answers of the sample members are designed to reflect and quantify the study parameters:

1-perceived education service

a. Education quality

b. Education supervision

2-student satisfaction in public universitiesThe mean value and standard deviation for each parameter will then be calculated for each parameter. The standard deviation will also be calculated. The rank and relative importance for each variable is reported to run as follows:

\subsubsection{Education quality}

As it is mentioned earlier, education quality parameter has five sub divisions. The table below shows all variables and their mean value, standard deviation, rank and importance for each.

Table (4-2): Description and evaluation of education quality

\begin{tabular}{l|l|l|l|l|l}
\hline No. & Item & $\begin{array}{l}\text { Mean } \\
\text { value }\end{array}$ & St-dev. & Rank & Importance \\
\hline 7. & $\begin{array}{l}\text { All university staff has good } \\
\text { appearance. }\end{array}$ & 5.71 & 1.25 & 3 & High \\
\hline 8. & $\begin{array}{l}\text { Classes have an engineering design } \\
\text { suitable for teaching. }\end{array}$ & 5.26 & 1.54 & 15 & High \\
\hline 9. & $\begin{array}{l}\text { Educational resources and needs are } \\
\text { available all over the time. }\end{array}$ & 5.03 & 1.68 & 25 & High \\
\hline 10. & Buildings and yards have a good & 5.72 & 1.35 & 2 & High \\
\hline
\end{tabular}




\begin{tabular}{c|l|l|l|l|l}
\hline 11. & $\begin{array}{l}\text { All university facilities are clean } \\
\text { and attractive. }\end{array}$ & 5.28 & 1.50 & 14 & High \\
\hline 12. & $\begin{array}{l}\text { Classes are comfortable for } \\
\text { sudents. }\end{array}$ & 5.05 & 1.58 & 24 & High \\
\hline 13. & University has a good decoration. & 4.92 & 1.55 & 29 & Medium \\
\hline 14. & Parking is available in university. & 4.27 & 1.85 & 38 & Medium \\
\hline 15. & $\begin{array}{l}\text { University offers new and updated } \\
\text { curricula. }\end{array}$ & 5.20 & 1.47 & 16 & High \\
\hline 16. & $\begin{array}{l}\text { Computers are available and } \\
\text { sufficient for students. }\end{array}$ & 4.90 & 1.59 & 30 & Medium \\
\hline 17. & $\begin{array}{l}\text { Internet service at university is good } \\
\text { and available. }\end{array}$ & 5.5 & 1.46 & 9 & High \\
\hline & Overall & 5.15 & 1.03 & & High \\
\hline
\end{tabular}

Reliability

\begin{tabular}{l|l|l|l|l|l}
\hline No. & Item & $\begin{array}{l}\text { Mean } \\
\text { value }\end{array}$ & St-dev. & Rank & Importance \\
\hline 18. & University employees are friendly. & 5.54 & 1.42 & 7 & High \\
\hline
\end{tabular}

\begin{tabular}{|c|c|c|c|c|c|}
\hline 19. & University instructors are friendly. & 5.60 & 1.33 & 6 & High \\
\hline 20. & $\begin{array}{l}\text { University structures are qualified } \\
\text { and efficient. }\end{array}$ & 5.65 & 1.31 & 4 & High \\
\hline 21. & $\begin{array}{l}\text { University structures use modern } \\
\text { teaching method. }\end{array}$ & 5.17 & 1.53 & 19 & High \\
\hline 22. & $\begin{array}{l}\text { University is highly compatible } \\
\text { with society. }\end{array}$ & 5.08 & 1.34 & 10 & High \\
\hline 23. & $\begin{array}{l}\text { University employees are well } \\
\text { informed about rules and } \\
\text { procedures. }\end{array}$ & 5.17 & 1.37 & 20 & High \\
\hline 24. & $\begin{array}{l}\text { Security and safety are provided by } \\
\text { university. }\end{array}$ & 5.51 & 1.33 & 8 & High \\
\hline & Overall & 5.15 & 1.03 & & High \\
\hline \multicolumn{6}{|c|}{ Assurance } \\
\hline No. & Item & $\begin{array}{l}\text { Mean } \\
\text { value }\end{array}$ & St-dev. & Rank & Importance \\
\hline 25. & $\begin{array}{l}\text { Adequate space is available for } \\
\text { registration. }\end{array}$ & 5.65 & 1.25 & 5 & High \\
\hline 26. & $\begin{array}{l}\text { University provides convenient time } \\
\text { for registration. }\end{array}$ & 5.36 & 1.46 & 12 & High \\
\hline 27. & University provides accurate & 4.97 & 1.63 & 26 & Medium \\
\hline
\end{tabular}




\begin{tabular}{|l|l|l|l|l|l|l|}
\hline registration procedures. & & & \\
\hline 28. & $\begin{array}{l}\text { The filing process at university is } \\
\text { organized. }\end{array}$ & 5.12 & 1.39 & 21 & High \\
\hline 29. & Instructors are punctual. & 5.83 & 1.29 & 1 & High \\
\hline 30. & $\begin{array}{l}\text { University employees care about } \\
\text { student's problems. }\end{array}$ & 5.19 & 1.52 & 18 & High \\
\hline$\quad$ Overall & 5.35 & 1.05 & & High \\
\hline Response & $\begin{array}{l}\text { Mean } \\
\text { No. }\end{array}$ & value & St-dev. & Rank & Importance \\
\hline 31. & $\begin{array}{l}\text { University provides qualified } \\
\text { mployees to help students. }\end{array}$ & 5.31 & 1.46 & 13 & High \\
\hline 32. & $\begin{array}{l}\text { University provides qualified } \\
\text { instructors to help students. }\end{array}$ & 5.40 & 1.42 & 10 & High \\
\hline 33. & $\begin{array}{l}\text { Instructors are able to solve } \\
\text { problems they have with their } \\
\text { tudents. }\end{array}$ & 5.20 & 1.47 & 17 & High \\
\hline
\end{tabular}

\begin{tabular}{|c|c|c|c|c|c|}
\hline 34. & $\begin{array}{r}\text { University employees are qualified } \\
\text { to solve student's problems. }\end{array}$ & 5.06 & 1.51 & 23 & High \\
\hline 35. & $\begin{array}{l}\text { Students can express their opinions } \\
\text { and complain about their problems. }\end{array}$ & 5.62 & 1.64 & 35 & Medium \\
\hline 36. & $\begin{array}{c}\text { University handle enquires } \\
\text { efficiently and quickly. }\end{array}$ & 4.62 & 1.64 & 36 & Medium \\
\hline \multicolumn{2}{|r|}{ Overall } & 5.03 & 1.25 & & High \\
\hline \multicolumn{6}{|c|}{ Empathy } \\
\hline No. & Item & $\begin{array}{l}\text { Mean } \\
\text { value }\end{array}$ & St-dev. & Rank & Importance \\
\hline 37. & $\begin{array}{l}\text { University pay attention to student's } \\
\text { affairs. }\end{array}$ & 4.83 & 1.71 & 32 & Medium \\
\hline 38. & $\begin{array}{r}\text { University provides sufficient } \\
\text { computer facilities. }\end{array}$ & 4.70 & 1.62 & 34 & Medium \\
\hline 39. & $\begin{array}{l}\text { University provides sufficient class } \\
\text { rooms which can hold all students. }\end{array}$ & 5.58 & 1.39 & 11 & High \\
\hline 40. & $\begin{array}{c}\text { University employees concerns a lot } \\
\text { about all students. }\end{array}$ & 4.88 & 1.59 & $\beta 1$ & Medium \\
\hline 41. & Instructors support and concern & 4.95 & 1.54 & 27 & Medium \\
\hline
\end{tabular}




\begin{tabular}{|l|l|l|l|l|l|}
\hline \multicolumn{2}{|c|}{ about student needs. } & & & \\
\hline 42. & $\begin{array}{l}\text { Time available at computer labs is } \\
\text { an adequate and suitable for all } \\
\text { students. }\end{array}$ & 4.79 & 1.61 & 33 & Medium \\
\hline $\begin{array}{l}\text { 43. } \\
\begin{array}{c}\text { University is fair and unbiased } \\
\text { when dealing with student's } \\
\text { problems. }\end{array}\end{array}$ & 4.58 & 1.74 & 37 & Medium \\
\hline \\
\hline
\end{tabular}

Table (4-3): Education service quality

\begin{tabular}{|l|l|l|l|l|l|}
\hline No. & Item & $\begin{array}{c}\text { Mean } \\
\text { value }\end{array}$ & St-dev. & Rank & Importance \\
\hline 1. & Tangibility & 5.15 & 1.03 & 3 & High \\
\hline 2. & Reliability & 5.39 & 1.04 & 1 & High \\
\hline 3. & Assurance & 5.35 & 1.05 & 2 & High \\
\hline 4. & Response & 5.03 & 1.25 & 4 & High \\
\hline 5. & Empathy & 4.87 & 1.24 & 5 & Medium \\
\hline
\end{tabular}

Tables (4-2) and table (4-3) demonstrate that education service available to engineering students in public universities in the south of Jordan is relatively high with a mean value of 5.16 and standard deviation of 0.96. Noteworthy here is that Reliability has the highest value with 5.39, 1.04 for its mean value and standard deviation respectively while Empathy has the lowest value with a mean value of 4.87 and a standard deviation of 1.24. The variables of reliability (instructors are punctual) has the highest importance rank with a mean value of 5.83 and standard deviation of 1.29 followed by the variables of tangibility (buildings and yards have a good appearance) with 5.72 and 1.35 mean value and standard deviation respectively. Meanwhile; the variable of tangibility (parking is available in university) has the lowest value with a mean value of 4.27 and a standard deviation of 1.85 .

\subsubsection{Supervision quality}

Description and evaluation of supervision quality measurement is illustrated in table (4-4) below:

Table (4-4): Supervision quality

\begin{tabular}{|l|l|l|l|l|l|}
\hline No. & Item & Mean value & St-dev. & Rank & Importance \\
\hline 44. & $\begin{array}{l}\text { Supervisor provides sufficient } \\
\text { time to the student. }\end{array}$ & 5.08 & 1.6 & 5 & High \\
\hline 45. & $\begin{array}{l}\text { Supervisor discuss subject } \\
\text { thoroughly through supervision. }\end{array}$ & 5.12 & 1.52 & 3 & High \\
\hline 46. & $\begin{array}{l}\text { Supervisor provides important } \\
\text { notes when supervise students. }\end{array}$ & 5.3 & 1.46 & 1 & High \\
\hline 47. & $\begin{array}{l}\text { Supervisor reacts positively } \\
\text { towards students' problems. }\end{array}$ & 5.21 & 1.45 & 2 & High \\
\hline 48. & $\begin{array}{l}\text { Supervisor feels about student's } \\
\text { research and analysis efforts. }\end{array}$ & 5.11 & 1.52 & 4 & High \\
\hline
\end{tabular}




\begin{tabular}{|c|c|c|c|c|c|}
\hline 49. & $\begin{array}{l}\text { Student feels comfortable after } \\
\text { meeting his/her supervisor. }\end{array}$ & 4.09. & 1.60 & 6 & Medium \\
\hline & Overall & 5.13 & 1.37 & & High \\
\hline
\end{tabular}

As it is mentioned in table (4-4): five out of six variables of supervision quality have big importance levels. The variables ('supervisor provides important notes and supervisor reacts positively towards students' problems) have 5.3 and 5.21 mean values respectively which is greater than 5.13 the overall mean value of the parameter (supervision).

\subsubsection{Student satisfaction}

Table (4-5) illustrates the statistical indicators of student satisfaction parameter.

Table (4-5): Student satisfaction

\begin{tabular}{|c|c|c|c|c|c|}
\hline No. & Item & Mean value & St-dev. & Rank & Importance \\
\hline 50. & $\begin{array}{l}\text { I feel comfortable because I } \\
\text { am a student in this university. }\end{array}$ & 5.07 & 1.81 & 1 & High \\
\hline 51. & $\begin{array}{l}\text { If I had another chance I } \\
\text { would register in this } \\
\text { university. }\end{array}$ & 4.64 & 1.98 & 4 & Medium \\
\hline 52. & $\begin{array}{l}\text { My future life will be safe } \\
\text { because I am in this university }\end{array}$ & 4,68 & 1.96 & $\beta$ & Medium \\
\hline 53. & $\begin{array}{l}\text { Being a student in this } \\
\text { university is one of my best } \\
\text { decisions. }\end{array}$ & 4.49 & 1.97 & 5 & Medium \\
\hline 54. & $\begin{array}{l}\text { I advise others to join this } \\
\text { university. }\end{array}$ & 4.73 & 1.90 & 2 & Medium \\
\hline & Overall & 4.72 & 1.77 & & Medium \\
\hline
\end{tabular}

Results of student satisfaction parameter analysis in table (4-5) above indicate that this parameter has a medium measurement with 4.72, 1.77 mean value and standard deviation respectively but the variables (I feel comfortable because I'm a student in this university) has a relatively high level with 5.07, 1.81 mean value and standard deviation respectively at the same time the variable ( being a student in this university is one of my best decisions) has the lowest level with a mean value 4.49 and a standard deviation of 1.97

Table (4-6): summary of parameters results

\begin{tabular}{|l|l|l|l|l|l|}
\hline No. & Item & $\begin{array}{l}\text { Mean } \\
\text { value }\end{array}$ & St-dev. & Rank & Importance \\
\hline 1. & Student orientation & 4.56 & 1.17 & 4 & Medium \\
\hline 2. & Education quality & 5.16 & 0.96 & 1 & High \\
\hline 3. & Supervision quality & 5.13 & 1.37 & 2 & High \\
\hline 4. & Student satisfaction & 4.72 & 1.77 & 3 & Medium \\
\hline
\end{tabular}




\subsection{Testing of hypotheses}

In this sector, evaluation of study hypothesis will be carried out by using statistical methods like simple linear regression, multilinear regression, F-test and T-test in order to find the accepted and rejected stated hypothesis. Acceptance or rejection of each hypotheses depends on the value of significance level, if the significance level is less than 0.05 , the null hypotheses rejected and the alternative one accepted and vice versa.

\subsubsection{Testing of first hypothesis}

The first hypothesis states that: "there is no influence of statistical significance of student orientation on their satisfaction at significant level of 0.05 ".This hypothesis will be tested in this section. To test this hypothesis, simple linear regression method is used. taking into consideration that the independent variable is the student orientation and the dependent variable is "student satisfaction" of engineering students in public universities in the south of Jordan as illustrated in table (4-7) below:

Table (4-7): Analysis of the relation between student orientation and student satisfaction in public universities

\begin{tabular}{|c|c|c|c|c|c|c|c|c|c|}
\hline \multirow{2}{*}{$\begin{array}{l}\text { Independent } \\
\text { variable }\end{array}$} & \multirow[t]{2}{*}{ R2 } & \multirow[t]{2}{*}{$\mathrm{F}$} & \multirow{2}{*}{$\begin{array}{l}\text { Degree } \\
\text { of } \\
\text { freedom }\end{array}$} & \multirow{2}{*}{$\begin{array}{l}\text { Sig. } \\
\text { leve }\end{array}$} & \multicolumn{5}{|c|}{ Regression coefficient } \\
\hline & & & & & Item & B & $\begin{array}{l}\text { Standard } \\
\text { error }\end{array}$ & $T$ & level \\
\hline $\begin{array}{l}\text { Education } \\
\text { quality }\end{array}$ & 0.359 & 113.52 & \begin{tabular}{|l|}
1 \\
253 \\
254
\end{tabular} & 0.00 & $\begin{array}{l}\text { Student } \\
\text { orientation }\end{array}$ & 0.599 & 0.056 & 10.635 & 0.000 \\
\hline
\end{tabular}

Results in table (4-7) shows that:simple regression model for the effect of student orientation as a dependent variable on a student satisfaction variable as an independent variable is significant with 0.05 significance level and f-value calculated is 113.52 with $\mathrm{R}^{2}$ value of 0.359 so the student satisfaction explains $36 \%$ of student satisfaction. In addition, regression coefficient of 0.599 indicates that the total effect of student orientation on student satisfaction is positively significant at a significant level of 0.05.Therefore; the null hypothesis should be rejected and the alternative accepted."there is statistically significant relation of student orientation on student satisfaction of engineering students in public universities".

\subsubsection{Testing of second hypothesis}

The second hypothesis states that: "There is no influence of statistical significance of student orientation on quality of educational service in the public universities" This hypothesis is divided into two sub hypotheses as follows:

a- The first hypothesis:"There is no statistical significance influence of student orientation of education quality of engineering students in public universities" Table (4-8) shows that the statistical analysis of simple linear regression test taking into consideration that student orientation represents independent variable while the education quality represents dependent variable. 
Table (4-8): Influence of student orientation on education quality.

\begin{tabular}{|c|c|c|c|c|c|c|c|c|c|}
\hline \multirow{2}{*}{$\begin{array}{l}\text { Independent } \\
\text { variable }\end{array}$} & \multirow[t]{2}{*}{$\mathrm{R}^{2}$} & \multirow{2}{*}{$\begin{array}{l}\text { F } \\
\text { calculated }\end{array}$} & \multirow{2}{*}{$\begin{array}{l}\text { Degree } \\
\text { of } \\
\text { freedom }\end{array}$} & \multirow{2}{*}{$\begin{array}{l}\text { Significant } \\
\text { level }\end{array}$} & \multicolumn{5}{|c|}{ Regression coefficient } \\
\hline & & & & & Item & B & $\begin{array}{l}\text { Standard } \\
\text { error }\end{array}$ & $t$ & $\begin{array}{l}\text { Sig- } \\
\text { level }\end{array}$ \\
\hline \multirow{3}{*}{$\begin{array}{l}\text { Education } \\
\text { quality }\end{array}$} & \multirow[t]{3}{*}{0.425} & \multirow[t]{3}{*}{150.185} & 1 & \multirow[t]{3}{*}{0.000} & \multirow{3}{*}{$\begin{array}{l}\text { Student } \\
\text { orientation }\end{array}$} & \multirow[t]{3}{*}{0.652} & \multirow[t]{3}{*}{0.053} & \multirow[t]{3}{*}{12.255} & \multirow[t]{3}{*}{0.000} \\
\hline & & & 253 & & & & & & \\
\hline & & & 254 & & & & & & \\
\hline
\end{tabular}

It is obvious that there is a positive total influence on education quality by student orientation at a significant level 0.05 by 0,65 with t-value of 12.255 and 0.000 significant level value which is less than 0.05 and the model is positively significant with F-value of 150.185 at 0.05 significant level. Student satisfaction variable explain $43 \%$ of the differences in education quality service. Therefore; the null hypothesis is rejected, and the following hypothesis accepted: "student orientation has statistically significant positive relation and effect on education quality in public universities."

b. the second sub hypothesis

the second sub hypothesis states that: student orientation has no effect on supervision quality in public universities. Simple linear regression is used to test this sub hypothesis taking into account that student orientation represents independent variable and supervision quality represents dependent variable, the result of analysis is shown in table (4-9) below.

Table (4-9): Influence of student orientation on supervision quality

\begin{tabular}{|c|c|c|c|c|c|c|c|c|c|}
\hline \multirow{2}{*}{$\begin{array}{l}\text { Independent } \\
\text { variable }\end{array}$} & \multirow[t]{2}{*}{$\mathrm{k}^{2}$} & \multirow{2}{*}{ calculated } & \multirow{2}{*}{$\begin{array}{l}\text { Degree } \\
\text { of } \\
\text { freedom }\end{array}$} & \multirow{2}{*}{$\begin{array}{l}\text { Significant } \\
\text { level }\end{array}$} & \multicolumn{5}{|c|}{ Regression coefficient } \\
\hline & & & & & Item & B & $\begin{array}{l}\text { Standard } \\
\text { error }\end{array}$ & t & $\begin{array}{l}\text { Sig- } \\
\text { level }\end{array}$ \\
\hline $\begin{array}{l}\text { Supervision } \\
\text { quality }\end{array}$ & 0.241 & 64.296 & $\frac{1}{253}$ & 0.000 & $\begin{array}{l}\text { Student } \\
\text { orientation }\end{array}$ & 0.49 & 0.061 & 8.018 & 0.000 \\
\hline
\end{tabular}

Result of statistical analysis in table (4-9) above show a total effect of student orientation variable on supervision quality variable of value of 0.49 which means that the supervision quality will vary by a ratio of 0.49 for every degree of student orientation. the t-value was calculated to be 8.018 which makes is significant at a significant level of 0.05 . at the same time:

the student orientation can explain $24 \%$ of differences in supervision quality.Based on these numbers and the previous argument; the null hypothesis is rejected and the alternative one is accepted; therefore:"student orientation has significant positive relation and effect on supervision quality in public universities."Based on the results of testing the two-sub hypotheses above, the main hypothesis is rejected, and the following result can be deduced:"student orientation has positive effect on perceived education quality service (education quality and supervision quality) of engineering students in public universities in the south of Jordan."

\subsubsection{Testing of third hypothesis}

The hypothesis states that:"there is no influence of statistical significant of quality of perceived education service on student's satisfaction of engineering students in public universities."This main hypothesis is divided into two sub hypotheses.the first one measures the effect of education quality on student satisfaction. and the second one measures the supervision quality on student satisfaction of engineering students in public universities in the south of Jordan. 


\subsubsection{Testing the first sub hypothesis}

The simple linear regression method is used to measure the effects of dependent variable represented by education quality on the independent variable represented by student satisfaction and the results are illustrated in table (4-10) below

Table (4-10): Effect of education quality on student satisfaction

\begin{tabular}{|c|c|c|c|c|c|c|c|c|c|}
\hline \multirow{2}{*}{$\begin{array}{l}\text { Independent } \\
\text { variable }\end{array}$} & \multirow[t]{2}{*}{$\mathrm{R}^{2}$} & \multirow{2}{*}{$\begin{array}{l}\text { F } \\
\text { calculated }\end{array}$} & \multirow{2}{*}{$\begin{array}{l}\text { Degree } \\
\text { of } \\
\text { freedom }\end{array}$} & \multirow{2}{*}{$\begin{array}{l}\text { Significant } \\
\text { level }\end{array}$} & \multicolumn{5}{|c|}{ Regression coefficient } \\
\hline & & & & & Item & B & $\begin{array}{l}\text { Standard } \\
\text { error }\end{array}$ & $\mathrm{T}$ & $\begin{array}{l}\text { Sig- } \\
\text { level } \\
\end{array}$ \\
\hline \multirow{3}{*}{$\begin{array}{l}\text { Student } \\
\text { satisfaction }\end{array}$} & \multirow[t]{3}{*}{0.432} & \multirow[t]{3}{*}{154.422} & 1 & \multirow[t]{3}{*}{0.000} & \multirow{3}{*}{$\begin{array}{l}\text { Education } \\
\text { quality }\end{array}$} & \multirow[t]{3}{*}{0.657} & \multirow[t]{3}{*}{0.053} & \multirow[t]{3}{*}{12.427} & \multirow[t]{3}{*}{0.000} \\
\hline & & & 253 & & & & & & \\
\hline & & & 254 & & & & & & \\
\hline
\end{tabular}

Results stated in table (4-10) indicate that education service has a total positive effect on student satisfaction with a ratio of 0.657 . At the same time: education service explains $43 \%$ of difference in the value of student satisfaction variable. In addition to the significance of the model which has an F. calculated value of (154.422) therefore, the null hypothesis is rejected and the alternative one accepted as follows: "Education quality has a statistical and significant relation and positive effect on engineering student satisfaction in public universities."

\subsubsection{Testing the second sub hypothesis}

The same procedure used in testing the first sub hypothesis will be used to test the second one.The second sub-hypothesis states that:"there is no significant relation or effect of supervision quality on engineering student's satisfaction in public universities in the south of Jordan". The results of the simple linear regression are shown in table (4-11).

Table (4-11): Effect of supervision quality on student satisfaction

\begin{tabular}{|c|c|c|c|c|c|c|c|c|c|}
\hline \multirow{2}{*}{$\begin{array}{l}\text { Independent } \\
\text { variable }\end{array}$} & \multirow[t]{2}{*}{$\mathrm{R}^{2}$} & \multirow{2}{*}{$\begin{array}{l}\text { F } \\
\text { calculated }\end{array}$} & \multirow{2}{*}{$\begin{array}{l}\text { Degree } \\
\text { of } \\
\text { freedom }\end{array}$} & \multirow{2}{*}{$\begin{array}{l}\text { Significant } \\
\text { level }\end{array}$} & \multicolumn{5}{|c|}{ Regression coefficient } \\
\hline & & & & & Item & $\mathrm{B}$ & $\begin{array}{l}\text { Standard } \\
\text { error }\end{array}$ & $\mathrm{t}$ & $\begin{array}{l}\text { Sig- } \\
\text { level }\end{array}$ \\
\hline \multirow{3}{*}{$\begin{array}{l}\text { Student } \\
\text { satisfaction }\end{array}$} & \multirow[t]{3}{*}{0.317} & \multirow[t]{3}{*}{94.274} & 1 & \multirow[t]{3}{*}{0.000} & \multirow{3}{*}{$\begin{array}{l}\text { Supervision } \\
\text { quality }\end{array}$} & \multirow[t]{3}{*}{0.563} & \multirow[t]{3}{*}{0.058} & \multirow[t]{3}{*}{9.709} & \multirow[t]{3}{*}{0.000} \\
\hline & & & 253 & & & & & & \\
\hline & & & 254 & & & & & & \\
\hline
\end{tabular}

Results in table (4-11) indicate the significance of the simple linear regression model which measures the effect of supervision quality on student satisfaction that has an F- calculated value of 94.274 at significant level of 0.05 , and the supervision quality parameter explain a ratio of $32 \%$ of differences in independent variable ( student satisfaction ) in addition to the total effect of supervision quality on student satisfaction with a value of 0.563 and t- value of 9.709 at significant level of 0.05 , so, the null hypothesis is rejected the following alternative one is accepted. "Supervision quality has a statistical and significant relation and positive effect on student satisfaction of engineering students in public universities".

Based on the testing results of the two-sub hypothesis above, the main hypothesis is rejected and the following one is accepted. "Perceived education service quality has positive significant effect on engineering student satisfaction in public universities in the south of Jordan".

\subsubsection{Testing of Fourth hypothesis}

This hypothesis states that:"There is no indirect statistical significant influence of student orientation on student satisfaction with the presence of perceived education service quality as intermediate variables ".To testify this hypothesis, path analysis is used which supposes that there is no multicollinearity among dependent variables which are represented by student orientation as a main dependent variable and supervision quality and education quality are intermediate dependent variables, so, stepwise regression is 
used to verify this assumption. And the results are illustrated in table (4-12).

Table (4-12): Effect of student orientation, education quality, supervision quality on student satisfaction.

\begin{tabular}{|c|c|c|c|c|c|c|c|c|c|}
\hline model & $\mathrm{R}^{2}$ & $\begin{array}{l}\text { F } \\
\text { calculated }\end{array}$ & $\begin{array}{l}\text { Degree } \\
\text { of } \\
\text { freedom }\end{array}$ & $\begin{array}{l}\text { Significant } \\
\text { level }\end{array}$ & Item & $B$ & $\begin{array}{l}\text { Standard } \\
\text { error }\end{array}$ & $T$ & $\begin{array}{l}\text { Sig- } \\
\text { level }\end{array}$ \\
\hline \multirow[t]{3}{*}{ ist } & \multirow[t]{3}{*}{0.432} & \multirow[t]{3}{*}{154.422} & 1 & \multirow[t]{3}{*}{0.000} & \multirow{3}{*}{$\begin{array}{l}\text { Education } \\
\text { quality }\end{array}$} & \multirow[t]{3}{*}{0.657} & \multirow[t]{3}{*}{0.053} & \multirow[t]{3}{*}{12.427} & \multirow[t]{3}{*}{0.000} \\
\hline & & & 253 & & & & & & \\
\hline & & & 254 & & & & & & \\
\hline \multirow[t]{3}{*}{ 2nd } & \multirow[t]{3}{*}{0.482} & \multirow[t]{3}{*}{94.159} & 2 & \multirow[t]{3}{*}{0.000} & \multirow{2}{*}{$\begin{array}{l}\text { Education } \\
\text { quality }\end{array}$} & \multirow[t]{2}{*}{0.464} & \multirow[t]{2}{*}{0.067} & \multirow[t]{2}{*}{6.952} & \multirow[t]{2}{*}{0.000} \\
\hline & & & 252 & & & & & & \\
\hline & & & 254 & & $\begin{array}{l}\text { Student } \\
\text { orientation }\end{array}$ & 0.296 & 0.067 & 4.437 & 0.000 \\
\hline \multirow[t]{4}{*}{${ }_{3} \mathrm{rd}$} & \multirow[t]{4}{*}{0.517} & \multirow[t]{4}{*}{154.422} & 1 & \multirow[t]{4}{*}{0.000} & Education & \multirow[t]{2}{*}{0.359} & \multirow[t]{2}{*}{0.070} & \multirow[t]{2}{*}{5.106} & \multirow[t]{2}{*}{0.000} \\
\hline & & & 253 & & quality & & & & \\
\hline & & & \multirow[t]{2}{*}{254} & & $\begin{array}{l}\text { Student } \\
\text { orientation }\end{array}$ & 0.251 & 0.066 & 3.817 & 0.000 \\
\hline & & & & & $\begin{array}{l}\text { Supervision } \\
\text { quality }\end{array}$ & 0.232 & 0.061 & 3.785 & 0.030 \\
\hline
\end{tabular}

As it is expected when using SPSS statistical programs in the first model of the most interpreted variable (education quality) is entered, in other words, it is the same way of measuring the effect of education quality on student satisfaction. In the second model student orientation is added and it is found that both variable interpret $48 \%$ of difference in student satisfaction with about 5\%increase on the first model:The interpretation of student satisfaction difference raised up to $52 \%$ when supervision quality is added to model two. So, there is no multicollinearity among dependent variables.AMOS program is used to analyse the path to verify the Fourth hypothesis. Table (4-13) shows results almost similar to those found when using SPSS program before with respect to the direct effect of variables on paths.

\section{4. conclusions}

The following main conclusions were accomplished:

- The student orientation level in the universities under investigation of this research is medium.

- The education service quality level in the universities under investigation of this research is relatively high.

- The tangibility, reliability, assurance and response levels of education service quality in the universities under investigation of this research are relatively high.

- The empathy level of education service quality in universities under investigation of this study is medium.

- The supervision quality level of engineering students in in universities under investigation of this study is high.

- The engineering student satisfaction level in universities under investigation of this study is medium.

- there is a strong relation and high correlation between student orientation, perceived education service (supervision quality, education quality) and student satisfaction.

- The study emphasizes the direct influence of student orientation on achieving high level of student satisfaction when perceived education service and the intermediate parameters (supervision quality, education quality) were taken into consideration.

- The relationship between student orientation and student satisfaction is greatly influenced directly and indirectly by education service quality. 


\section{5. recommendations}

Based on the research and the findings deduced from it; This study recommends the following:

- Universities should pay attention to achieve student satisfaction because students consider it a comprehensive evaluation of education service and student orientation.

- Universities should pay more attention to its students to increase its student orientation because the study unveiled considerable influence of student orientation on education quality and student satisfaction.

- Universities should improve all levels of quality through paying attention to quality dimensions (tangibility, reliability, assurance, response and empathy).

- The study indicates that there is a need to improve supervision quality because this factor goes parallel with education quality for engineering students as was proved from the great accomplishment of student satisfaction due to improved supervision quality.

- Service quality has direct positive influence on student satisfaction as well as enhancing student orientation influence on student satisfaction, so, universities should pay more attention to service quality.

\section{References}

Mukhtar, U., Anwar, S., Ahmed, U. \& Baloch, M. A., 2015. Factors effecting the service quality of public and private sector universities comparatively: an empirical investigation. Arts, Science \& Commerce, pp. 132-142.

Escotet, M. A., 2012. Scholarly Blog. [Online] Available at: http://miguelescotet.com/2012/what-is-the-purposeof-higher-education knowledge-or-utility/[Accessed 25 2017].

Fortino, A., 2012. The Purpose of Higher Education: To Create Prepared Minds. [Online] Available at: https://evolllution.com/opinions/the-purpose-of-higher-education-to-create-prepared-minds/ [Accessed 25 2017].

DeShields Jr, O. W., Ali, K. \& Erdener, K., 2005. Determinants of business student satisfaction and retention in higher education: applying Herzberg's two-factor theory. International Journal of Educational Management, 19(2), pp. 128-139.

Yusoff, M., McLeay, F. \& Woodruffe-Burto, H., 2015. Dimensions driving business student satisfaction in higher education. Quality Assurance in Education, pp. 86-104.

Saif, N. I., 2014. The Effect of Service Quality on Student Satisfaction: A Field Study for Health Services Administration Students. International Journal of Humanities and Social Science, pp. 172-181.

Ilyas, M. \& Arif, S., 2013. Quality of work-life model for teachers of private universities in. Quality Assurance in Education, pp. 282-298.

Hon, w., 2002. Applying customer satisfaction theory to community college planning of student services. Insight in Student Services, Vol. 2.

Rad, A. \& Yarmohammadian, M., 2006. A study of relationship between managers' leadership style and employees' job satisfaction. Leadership in Health Services, pp. 11-26.

Kotler, P. \& Keller, K., 2012. Marketing Management. NJ: Prentice Hall. Petruzzellis, L., D’Uggento, A. M. \& Romanazzi, S., 2006. Student satisfaction and quality of service in Italian universities. Managing Service Quality, pp. 349-364. 
Mukhtar, U., Anwar, S., Ahmed, U. \& Baloch, M. A., 2015. Factors effecting the service quality of public and private sector universities comparatively: an empirical investigation. Arts, Science \& Commerce, pp. 132-142.

Oliver, R., 1997. Satisfaction: A Behavioral Perspective on the Consumer. New York: McGraw-Hill.

Elliott, K. \& Healy, M., 2001. Key factors influencing student satisfaction related to recruitment and retention. Journal of Marketing for Higher Education, pp. 1-11.

Navarro, M. M., Iglesias, M. P. \& Torres, P. R., 2005. A new management element for universities: satisfaction with the offered courses. International Journal of Educational Management, 19(6), pp. 505-526.

Elliott, K. \& Shin, D., 2002. Student satisfaction: an alternative approach to assessing this Important Concept. Journal of Higher Education Policy and Management,, pp. 97-109.

Mukhtar, U., Anwar, S., Ahmed, U. \& Baloch, M. A., 2015. Factors effecting the service quality of public and private sector universities comparatively: an empirical investigation. Arts, Science \& Commerce, pp. 132-142.

Carey, K., Cambiano, R. \& De Vore, J., 2002. Student to faculty satisfaction at a Midwestern university in the USA. pp. 93-97.

Marzo-Navarro, M., Iglesias, M. \& Torres, M., 2005. A new management element for universities: satisfaction with the offered courses. International Journal of Educational Management, 19(6), pp. 505-526.

Appleton-Knapp, S. \& Krentler, K., 2006. Measuring student expectations and their effects on satisfaction: the importance of managing student expectations. Journal of Marketing Education, pp. 254-264.

Wilkins, S. \& Balakrishnan, M. S., 2013. Assessing student satisfaction in transnational higher education. International Journal of Educational Management, pp. 146-153.

Garcl a-Aracil, A., 2009. European graduates' level of satisfaction with higher education. Journal of Higher Education, 57(1), pp. 1-21.

Kuh, G. \& Hu, S., 2001. The effects of student-faculty interaction in the 1990s. Review of Higher Education, 24(3), pp. 309-332.

Sojkin, B., Bartkowiak, P. \& Skuza, A., 2012. Determinants of higher education choices and student satisfaction: the case of Poland. Higher Education, 63 (5), pp. 565-81.

Douglas, J., Douglas, A. \& Barnes, B., 2006. Measuring student satisfaction at a UK university. Quality Assurance in Education, pp. 251-267.

Palacio, A., Meneses, G. \& Perez, P., 2002. The configuration of the university image and its relationship with the satisfaction of students. Journal of Educational Administration, 40(5), pp. 486-505.

Waugh, R. F., 2002. Academic staff perceptions of administrative quality at universities. Journal of Educational Administration, 40(2), pp. 172-188. 